\title{
Sistem Berbasis Pengetahuan Tumbuhan Obat Pusat Studi Biofarmaka
}

\author{
(Medicines Plant Knowledge Based System for Biopharmaca Research Centers)
}

Penulis

Afiliasi

\author{
Aini Fazriani ${ }^{{ }^{*}}$, Wisnu Ananta Kusuma ${ }^{1,2}$, Irmanida Batubara ${ }^{2,3}$ \\ ${ }^{1}$ Departemen Ilmu Komputer, Fakultas Matematika Ilmu Pengetahuan Alam, Institut Pertanian \\ Bogor, Bogor, Indonesia \\ ${ }^{2}$ Pusat Studi Biofarmaka Tropika, Lembaga Penelitian dan Pengabdian kepada Masyarakat, \\ Institut Pertanian Bogor, Bogor, Indonesia \\ ${ }^{3}$ Departemen Kimia, Fakultas Matematika Ilmu Pengengetahuan Alam, Institut Pertanian Bogor, \\ Bogor, Indonesia
}

\section{Kata Kunci \\ $\rightarrow$ Ontology \\ P Pengetahuan \\ $\rightarrow$ Senyawa \\ $\rightarrow$ Tumbuhan obat \\ Keywords \\ $\rightarrow$ Compound \\ $\Rightarrow$ Knowledge \\ $\rightarrow$ Medicinal plants \\ ○ Ontology}

Diterima 10 Januari 2019

Direvisi 18 Februari 2019 Disetujui 14 Maret 2019

* Penulis Koresponding Aini Fazriani email: aini_fazriani@apps.ipb.ac.id

\section{ABSTRAK}

Jamu terdiri atas berbagai macam tumbuhan obat yang diolah. Tumbuhan obat memiliki kandungan senyawa metabolit sekunder yang berperan sebagai khasiat. Pengetahuan tumbuhan obat beserta senyawanya perlu dikembangkan lagi menjadi pengetahuan eksplisit yang lebih spesifik dan mudah dimengerti sehingga berguna untuk masyarakat. Maka dari itu perlu mengembangkan sistem untuk digunakan oleh masyarakat sehingga pengobatan dengan tanaman obat lebih populer di kalangan masyarakat luas. Penelitian yang dilakukan mengenai manajemen pengetahuan berbasis ontologi terkait dengan tumbuhan obat dan senyawa. Penelitian ini menggunakan pendekatan proses manajemen pengetahuan model $\mathrm{SECl}$, selain itu pengembangan ontologi menggunakan metode Ontology building life cycle, sedangkan bahasa representasi yang digunakan adalah Resource Description Framework (RDF) dan Web Ontology Language (OWL) dengan toolsProtégé5.0. Pengembangan model ontologi dengan bahasa representasi RDF/OWL dapat menghasilkan pengetahuan dengan melakukan query menggunakan SPARQL. Hasil query tersebut dapat digunakan untuk diimplementasikan pada mobile.

\section{ABSTRACT}

Jamu (herbs) consists of various kinds of medicinal plants that are processed. Medicinal plants contain secondary metabolites which act as properties. Knowledge of medicinal plants and their compounds needs to be further developed into explicit knowledge that is more specific and easy to understand so that it is useful for the community. Therefore it is necessary to develop a system for use by the community so that treatment with medicinal plants is more popular among the wider community. Research conducted on the management of ontology-based knowledge related to medicinal plants and compounds. This study uses the SECI model knowledge management process approach, also, the development of ontology uses the Ontology building life cycle method, while the representation language used is the Resource Description Protocol (RDF) and Web Ontology Language (OWL) with Protégé5.0 tools. The development of ontology models with RDF / OWL representation languages is able to generate knowledge by performing queries using SPARQL. The results of these queries is able to be used to be implemented on mobile. 


\section{PENDAHULUAN}

Indonesia Jamu-Herbs (ljah) Analitik dikembangkan oleh Pusat Studi Biofarmaka Tropika (TropBRC) dan Departemen IImu Komputer, IPB yang merupakan sistem untuk mencari prediksi khasiat formula jamu menggunakan pendekatan machine learning (PLS-DA, M-PLS, SVM, dan VFI5). Banyak manfaat dari ljah Analitik yaitu untuk mengetahui konektivitas dari tumbuhan ke senyawa ke protein dan akhirnya terhadap penyakit, mengetahui protein atau penyakit yang ditargetkan dengan menginputkan tumbuhan atau senyawa, serta sebaliknya dan dapat memvalidasi atau memeriksa secara silang beberapa komposisi tumbuhan, yaitu formula jamu yang memiliki khasiat tertentu (ljah 2017).

Pengetahuan tentang tumbuhan obat, senyawa, protein, dan penyakit di ljah Analitik, perlu dikembangkan khususnya untuk pengetahuan tumbuhan obat dan senyawa metabolit sekunder yang berperan sebagai obat. Pengetahuan eksplisit ini dikembangkan lagi menjadi pengetahuan eksplisit yang lebih spesifik dan mudah dimengerti sehingga berguna untuk masyarakat pada umumnya. Oleh sebab itu, pengetahuan harus mempunyai wadah pengetahuan tersendiri, basis pengetahuan dapat digunakan sebagai wadah dari pengetahuan tersebut. Menurut Ribino et al. (2009) hubungan dan konsep basis pengetahuan dijelaskan menggunakan struktur ontologis dari instance untuk mengumpulkan dan mengelola data. Banyak data tumbuhan obat dan senyawa yang saling berhubungan, data tersebut perlu direpresentasikan ke dalam ontologi agar dapat ditransfer dengan mudah dan dapat digunakan kembali untuk masyarakat dan para peneliti di TropBRC khususnya untuk penelitian ke depannya.

Ontologi dikembangkan dengan bahasa Ontology Web Language (OWL) yang memiliki kelebihan dalam merepresentasikan sebuah domain serta hubungan yang ada di dalam domain tersebut, karena OWL dapat mendefinisikan relasi antar class dan karakteristik dari properties (Zhu dan Tao 2014). Menurut Sanjaya (2014) ontologi dapat dijadikan sebagai alternatif pemodelan basis data karena sifatnya fleksibel terhadap penambahan relasi baru dibanding dengan model basis data relasional. Selain itu, menurut Sir et al. (2015) basis data dibuat sebagai gudang data, sedangkan ontologi dibentuk untuk menjembatani komunikasi antara manusia dan mesin. Kedua sistem ini menggunakan penciptaan yang berbeda. Sistem basis data dibuat dari nol, yang artinya semua tabel dan isinya dirancang sendiri dari awal. Adapun saat merancang sebuah sistem ontologi, peneliti bisa memanfaatkan ontologi yang sudah ada, karena ontologi bebas dari paradigma sehingga ontologi lebih mudah diadopsi pada sistem apapun.

Banyak penelitian yang berhubungan tentang ontologi, seperti penelitian yang dilakukan oleh Chen (2010) yang membangun frame untuk mentransfer pengetahuan tacit berdasarkan ontologi menggunakan metode SECl. Mentransfer pengetahuan tacit adalah inti dari semua pengetahuan, dan memungkinkan untuk digunakannya kembali pengetahuan tersebut. Berdasarkan penelitian yang dilakukan oleh Silalahi (2015) membangun ontologi dengan Socio-Technical dengan banyak bertanya pada pakar-pakar ontologi tumbuhan untuk membangun medicinal plant ontology. Khan et al. (2017) membuat ontologi menggunakan semantic network ke dalam struktur frame dengan mendesain ontologi menggunakan Protégé 4.3.

Berdasarkan permasalahan di atas penelitian ini mempunyai tujuan merancang pengetahuan mengenai tumbuhan obat dan senyawa metabolit sekunder beserta pengetahuan dasar dari tumbuhan obat, dengan merepresentasikan model pengetahuan tersebut menggunakan teknik pemodelan ontologi. Model ontologi yang sudah dibuat direpresentasikan menggunakan SPARQL dan diimplementasikan ke dalam sistem tumbuhan obat berbasis mobile, perangkat mobile bisa bertindak sebagai penyedia konteks seperti web semantik, tetapi banyak aplikasi mobile yang serupa dengan sistem pengetahuan tumbuhan obat seperti yang telah dibuat oleh Balai Besar Penelitian dan Pengembangan Tanaman Obat dan Obat Tradisional (B2P2TOOT), sehingga pada penelitian ini lebih menekankan pada pengetahuan senyawa metabolit sekunder yang lebih spesifik lagi. Infomasi tentang pengetahuan ini dapat disebarkan kepada masyarakat luas untuk dikembangkan dan digunakan sehingga pengobatan dengan tanaman obat menjadi lebih populer lagi dikalangan masyarakat luas.

\section{METODE}

Pada tahapan penelitian ini dijelaskan detail langkah-langkah yang dilakukan dalam menentukan model ontologi yang sesuai untuk menunjang proses sistem berbasis pengetahuan di lingkungan TropBRC.

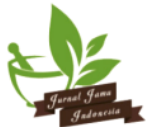


Metodologi penelitian yang digunakan untuk tahapan penelitian dapat dilihat pada Gambar 1.

Pada tahap awal menentukan kebutuhan sistem yang dibutuhkan TropBRC. Pada tahap ini juga dilakukan wawancara kepada pihak TropBRC yaitu Prof Dr Irmanida Batubara, SSi, MSi, mengenai penelitian yang dilakukan. Wawancara ini bertujuan untuk mengembangkan penelitian ljah Analitik sebelumnya kedalam sistem berbasis pengetahuan agar lebih mudah untuk dimengerti oleh masyarakat luas dan digunakan kembali oleh peneliti selanjutnya.

Pada tahap Discovery dan Capture kebutuhan pengetahuan menggunakan pengembangan pemetaan infrastruktur pengetahuan ke dalam proses SECl (Nonaka 1994). Proses ini dilakukan untuk menemukan, dan mengambil pengetahuan dari para pakar dan literatur.

Setelah semua informasi yang diperlukan sudah didapat, pada tahap sharing yang dilakukan adalah pengembangan ontologi yang dibangun menggunakan metode ontology building life cycle (Stevens et al. 2000). Tahap ini terdapat tahap pengidentifikasian tujuan dan ruang lingkup untuk menentukan kelas, properti beserta nilainya, lalu pengetahuan tersebut diakuisisi dan direpresentasikan ke dalam informasi baru dalam bentuk ontologi dengan membangun ontologi secara konseptual menggunakan bahasa representasi OWL dan menggunakan tools Protégé 5.0.
Protégéditemukan pada tahun 1989 adalah meta-tool yang digunakan dalam sistem berbasis pengetahuan. Protégé berfokus pada penggunaan pengetahuan meta untuk mengembangkan ontologi.

Konseptual ontologi yang telah dibuat di Protégé dikembangkan ke dalam sistem aplikasi mobile dengan merancang antar muka terlebih dahulu.Softwate Development Kit (SDK) digunakan untuk membangun aplikasi mobile, menggunakan tools Android Studio untuk melakukan coding.

Pengujian dilakukan sebagai proses validasi untuk menguji tes terhadap fungsionalitas sistem dengan menggunakan metode blackbox testing. Blackbox testing digunakan untuk dapat memastikan bahwa sistem memiliki fungsi yang tepat dan memastikan bahwa sistem memiliki output yang benar serta sudah sesuai dengan kebutuhan.

Lingkungan implementasi yang digunakan untuk menunjang penelitian ini adalah perangkat keras yang digunakan adalah komputer dengan spesifikasi AMD Quad-Core Processor A8-4500M APU with Radeon(tm) HD Graphics $1.90 \mathrm{GHz}$, Memory (RAM) 4.00 GB DDR3, Hard Disk 500 GB HDD, dan System Type 4-bit Operating System(Acer, Thamrin, Indonesia).Perangkat lunak yang digunakan adalah Protégé 5.0 untuk membuat ontologi, sedangkan untuk perancangan ontologi konseptual digunakan Microsoft Visio.

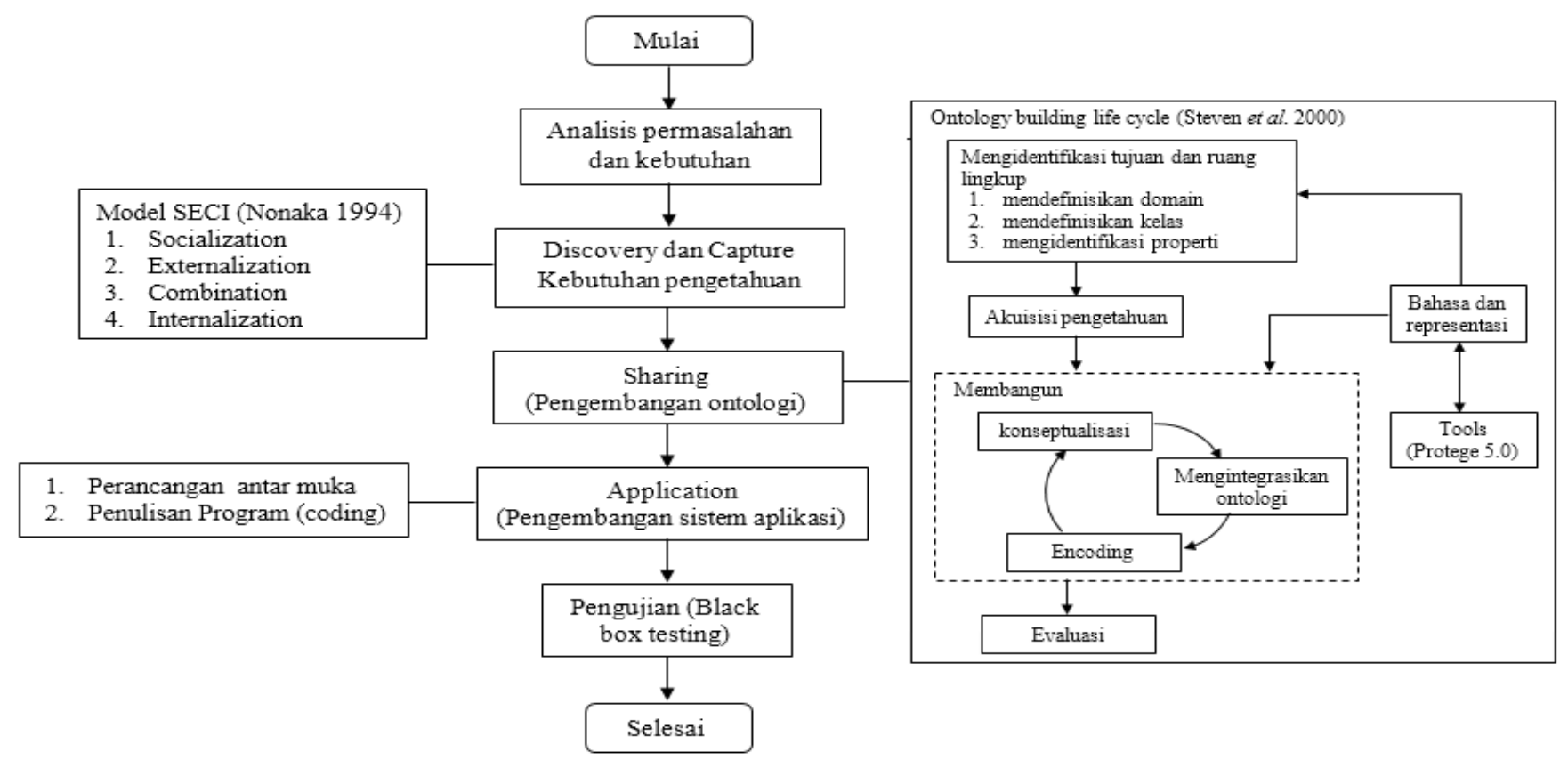

Gambar 1. Tahapan-tahapan penelitian 
HASIL DAN PEMBAHASAN

Analisis Permasalahan dan Kebutuhan Sistem

Memodelkan ontologi memerlukan domain pengetahuan untuk dijadikan batasan pengetahuan pada penelitian ini. Batasan yang digunakan dalam penelitian ini adalah domain yang terkait dengan informasi dasar dari pengetahuan tumbuhan obat serta kandungan senyawa metabolit tumbuhan tersebut. Domain yang digunakan dalam ontologi ini mengacu kepada kebutuhan pengetahuan tanaman obat di TropBRC. Domain-domain pengetahuan secara umum yang menjadi batasan pada penelitian ini meliputi domain tumbuhan, nama tumbuhan obat, taksonomi, cara pelestarian, kandungan kimia, habitat, bentuk tumbuhan, lokasi penyebaran serta efek dari tumbuhan obat.

\section{Discovery dan Capture Kebutuhan Pengetahuan Tumbuhan Obat}

Knowledge discovery adalah proses penemuan ataupun pengembangan pengetahuan dari informasi dan/ atau data atau perpaduan dari pengetahuan yang telah ada. Knowledge capture berkaitan dengan upaya mendapatkan tacit knowledge menjadi epxlicit sehingga explicit knowledge menjadi terorganisasi dan terkodifikasi.

Proses menemukan dan menangkap pengetahuan dilakukan untuk memenuhi kebutuhan pengetahuan tumbuhan obat sebelum dijadikan ontologi. Proses ini dilakukan untuk menemukan dan mengambil pengetahuan dari pakar serta literatur. Teknik penangkapan pengetahuan pada penilitian ini menggunakan metode SECI (Nonaka 1994). Pada tahap ini terdapat empat proses yaitu, Socialization, Externalization, Combination dan Internalization.

Socialization dalam penelitian ini adalah suatu kegiatan meng-capture pengetahuan mengenai pengetahuan tumbuhan obat yang masih berupa tacitknowledge dengan cara berdiskusi langsung dengan pakar untuk mengetahui informasi yang sebenarnya dan mengetahui informasi tumbuhan obat yang kurang dari literatur. Tujuan dari socialization ini adalah melakukan pertemuan untuk menceritakan pengalaman para pakar.

Eksternaliztion merupakan proses yang bertujuan untuk mengartikulasi tacitknowledge menjadi suatu konsep yang jelas atau explicit melalui proses dialog dan refleksi. Pada tahap ini, tacit to explicit yaitu mengekstrasikan apa yang ada dalam pikiran dan dituliskan lagi ke dalam dokumen. Informasi yang didapatdari pakar, ditulis ulang kembali untuk dijadikan ontologi konseptual. Hasil eksplorasi data dari tahap socialization di-eksternalisasi menjadi suatu ontologi konseptual yang nantinya dibangun menjadi sebuah sistem.

Pada tahap combination melakukan pengumpulan data untuk informasi tumbuhan obat yang nantinya digunakan sebagai ontologi dan dibangun lagi menjadi sistem berbasis pengetahuan tumbuhan obat. Informasi yang diperoleh dapat dari literatur dan web.

Pada tahap internalization terjadi proses konversi knowledge dari bentuk explicitknowledge yang berupa informasi pengetahuan tumbuhan obat berupa literatur ataupun dari internet yang didapat dari tahap combination, menjadi bentuk tacitknowledge berupa pengetahuan mengenai tumbuhan obat.

\section{Pengembangan Ontologi Tumbuhan Obat}

Berdasarkan domain-domain pengetahuan yang ditentukan, dilakukan pemetaan antar domain yang menjadi rancangan awal dari model ontologi konseptual dengan cara menghubungkan antar kelas dari setiap domain, pemetaan antar kelas dilakukan untuk mendapatkan rule (aturan) sehingga menghasilkan sebuah informasi yang nantinya menjadi sebuah pengetahuan.

\section{Mengidentifikasi Tujuan dan Ruang Lingkup}

Rancangan awal dari ontologi tanaman obat dapat ditentukan dengan menentukan kelas dan sub kelas dari domain yang telah ditentukan. Kelas dari domain tumbuhan obat yang digunakan pada penelitian ini menghasilkan kelas dan hierarkinya, dapat dilihat pada Gambar 2.

Kelas dan subkelas yang telah ditentukan, dibuat pemetaan antar kelas yang nantinya terbentuk sebuah trippel (subjek - predikat - obyek). Hasil pemetaan antar kelas menghasilkan sebuah relasi atau sering disebut propertiesdalam ontologi. Properties dalam ontologi memiliki sebuah domain atau rangeyang telah ditentukan, sehingga properties menghubungkan individu dari domain ke individu dari range. Properties ontologi memiliki dua macam properties yaitu object properties dan datatype properties.

Object properties mendeskripsikan relasi antara dua instances(individu) atau bisa disebut menghubungkan invididual dari domain ke individu range, sedangkan data properties mendeskripsikan relasi antara instances

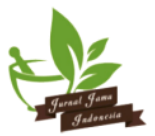


(individual) dan nilai data. Datatype properties Konseptualisasi Ontologi

menghubungkan individu ke nilai XML SchemaDatatype Pemetaan antar kelas seperti triplemodel yang atau rdf literal. merupakan struktur konsep dari ontologi menurut

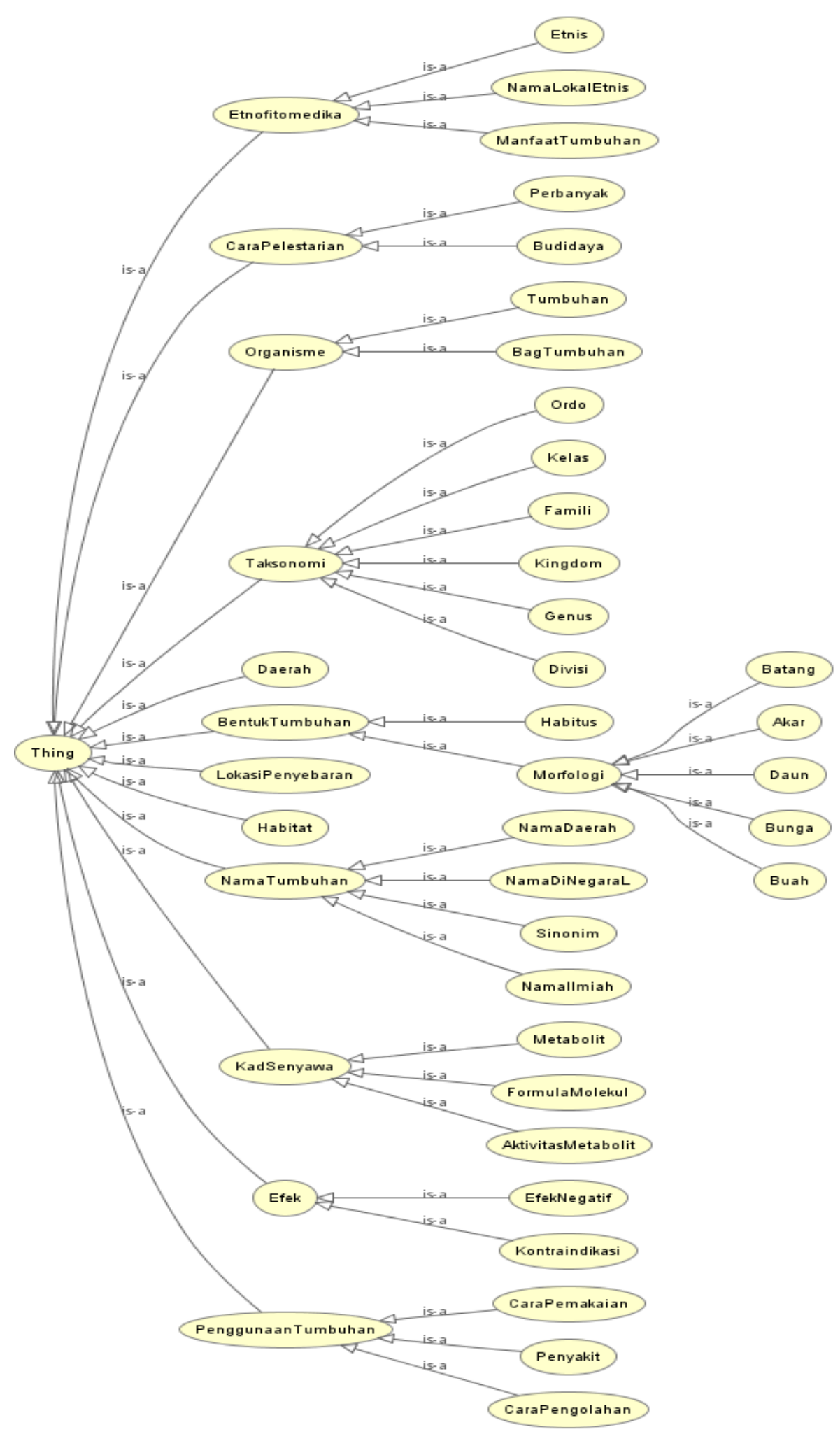

Gambar 2. Kelas dan hierarki tumbuhan obat 
Babu dan Govathoti (2017) membentuk sebuah model ontologi konseptual. Pemodelan ontologi konseptual yang digabungkan dari seluruh kelas dapat dilihat pada Gambar 3. Berdasarkan model konseptual yang sudah didapat, menghasilkan sebuah pengetahuan yang dapat dilihat pada Tabel 1, pengetahuan tersebut dibentuk menggunakan aturan berbentuk triple model yang dapat dilihat pada Tabel 2 .

Aturan-aturan pada Tabel 2 digunakan untuk membentuk pengetahuan. Berikut rule pengetahuan yang digunakan berdasarkan pengetahuan dari Tabel 1 dan aturan dari Tabel 2 dapat dilihat pada Tabel
3.Ruleyang terdapat pada Tabel 3 digunakan setelah pemodelan ontologi diiplementasikan pada toolsProtégé yang direpresentasikan menggunakan query SPARQL agar dapat digunakan oleh system sesuai dengan pengetahuan yang diinginkan maka dilakukan pengujian SPARQL. Berikut pengujian SPARQL untuk menampilkan pengetahuan delapan yang terdapat pada Tabel 1 berupa khasiat bagian tumbuhan berdasarkan aktivitas metabolit diimplementasikan pada tahap encoding menggunakan rule pengetahuan pada Tabel 3 dengan penulisan SPARQL dapat dilihat pada Gambar 5.

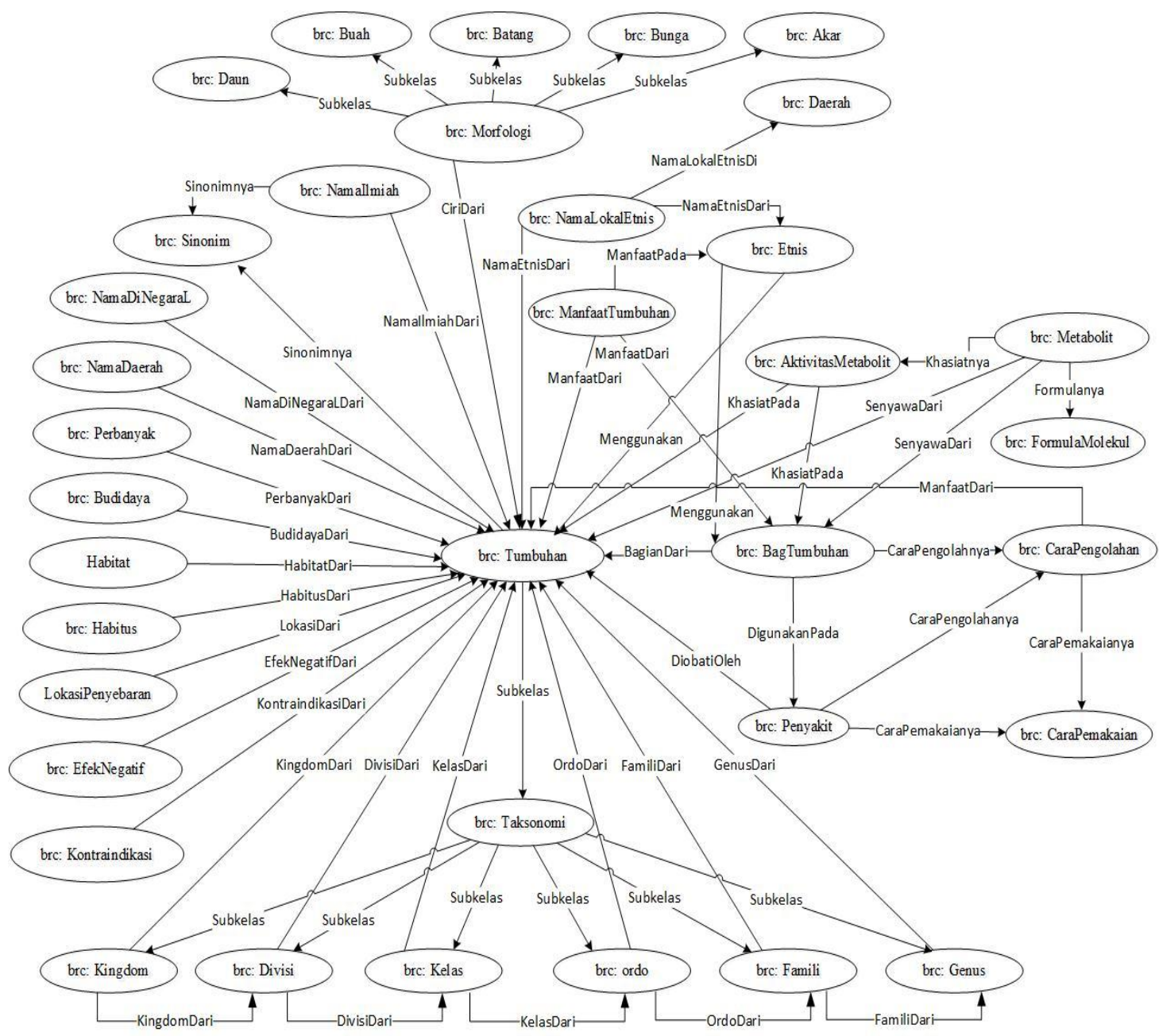

Gambar 3. Model konseptual tumbuhan obat 
Tabel 1. Pengetahuan yang dibentuk

\begin{tabular}{cl}
\hline Pengetahuan & \multicolumn{1}{c}{ Keterangan } \\
\hline 1 & Nama ilmiah dan sinonimdaritumbuhan \\
2 & Nama daerah dan asingdaritumbuhan \\
3 & Manfaat pada bagiantumbuhanberdasarkanetnis (etnofitomedika) \\
4 & Daerah suku, sertanamalokaletnisdaritumbuhan \\
5 & Cara pengolahan dan pemakaian bagiantumbuhanuntukpenyakittertentu \\
6 & Kandungansenyawa pada bagiantumbuhan \\
7 & Formula, berat molekul serta strukturmetabolit pada tumbuhan \\
8 & Khasiatbagiantumbuhanberdasarkanaktivitasmetabolit \\
9 & Efeknegatif dan kontraindikasidaritumbuhan \\
10 & Taksonomi pada tumbuhan \\
11 & Cara pelestariantumbuhanberdasarkanbudidaya dan perbanyak \\
12 & Habitat dan lokasidaritumbuhan \\
13 & Ciridaribentuktumbuhanberdasarkan habitus dan morfologi \\
\hline
\end{tabular}

Tabel 2. Aturan-aturan pada model konseptual (triple model)

\begin{tabular}{|c|c|c|c|}
\hline Rule & Variabel Subjek & Relasi/Predikat & Variabel Objek \\
\hline 1 & ?BagTumbuhan & ?BagianDari & ?Tumbuhan \\
\hline 2 & ?ManfaatTumbuhan & ?ManfaatDari & ?BagTumbuhan \\
\hline 3 & ?ManfaatTumbuhan & ?ManfaatDari & ?Tumbuhan \\
\hline 4 & ?ManfaatTumbuhan & ?ManfaatPada & ?Etnis \\
\hline 5 & ?Etnis & ?Menggunakan & ?BagTumbuhan \\
\hline 6 & ?Etnis & ?Menggunakan & ?Tumbuhan \\
\hline 7 & ?Etnis & ?DaerahnyaDi & ?Daerah \\
\hline 8 & ?NamaLokalEtnis & ?NamaLokalEtnisDi & ?Daerah \\
\hline 9 & ?NamaLokalEtnis & ?NamaEtnisDari & ?Etnis \\
\hline 10 & ?NamaLokalEtnis & ?NamaEtnisDari & ?Tumbuhan \\
\hline 11 & ?Namallmiah & ?NamallmiahDari & ?Tumbuhan \\
\hline 12 & ?Namallmiah & ?Sinonimnya & ?Sinonim \\
\hline 13 & ?Tumbuhan & ?Sinonimnya & ?Sinonim \\
\hline 14 & ?NamaDaerah & ?NamaDaerahDari & ?Tumbuhan \\
\hline 15 & ?NamaDiNegaraL & ?NamaDiNegaraLDari & ?Tumbuhan \\
\hline 16 & ?Kingdom & ?KingdomDari & ?Divisi \\
\hline 17 & ?Kingdom & ?KingdomDari & ?Tumbuhan \\
\hline 18 & ?Divisi & ?DivisiDari & ?Kelas \\
\hline 19 & ?Divisi & ?DivisiDari & ?Tumbuhan \\
\hline 20 & ?Kelas & ?KelasDari & ?Ordo \\
\hline 21 & ?Kelas & ?KelasDari & ?Tumbuhan \\
\hline 22 & ?Ordo & ?OrdoDari & ?Famili \\
\hline 23 & ?Ordo & ?OrdoDari & ?Tumbuhan \\
\hline 24 & ?Famili & ?FamiliDari & ?Genus \\
\hline 25 & ?Famili & ?FamiliDari & ?Tumbuhan \\
\hline 26 & ?Genus & ?GenusDari & ?Tumbuhan \\
\hline 27 & ?Habitat & ?HabitatDari & ?Tumbuhan \\
\hline 28 & ?Perbanyak & ?PerbanyakDari & ?Tumbuhan \\
\hline 29 & ?Budidaya & ?BudidayaDari & ?Tumbuhan \\
\hline 30 & ?LokasiPenyabaran & ?LokasiDari & ?Tumbuhan \\
\hline 31 & ?Habitus & ?HabitusDari & ?Tumbuhan \\
\hline 32 & ?Morfologi & ?CiriDari & ?Tumbuhan \\
\hline
\end{tabular}


Tabel 2. Aturan-aturan pada model konseptual (triple model) (Lanjutan)

\begin{tabular}{clll}
\hline Rule & \multicolumn{1}{c}{ Variabel Subjek } & \multicolumn{1}{c}{ Relasi/Predikat } & \multicolumn{1}{c}{ Variabel Objek } \\
\hline 33 & ?EfekNegatif & ?EfekNegatifDari & ?Tumbuhan \\
34 & ?Kontraindikasi & ?KontraindikasiDari & ?Tumbuhan \\
35 & ?Metabolit & ?SenyawaDari & ?BagTumbuhan \\
36 & ?Metabolit & ?SenyawaDari & ?Tumbuhan \\
37 & ?Metabolit & ?Khasiatnya & ?AktivitasMetabolit \\
38 & ?Metabolit & ?Formulanya & ?FormulaMolekul \\
39 & ?AktivitasMetabolit & ?KhasiatPada & ?Tumbuhan \\
40 & ?AktivitasMetabolit & ?KhasiatPada & ?BagTumbuhan \\
41 & ?BagTumbuhan & ?CaraPengolahanya & ?CaraPengolahan \\
42 & ?Penyakit & ?CaraPengolahanya & ?CaraPengolahan \\
43 & ?BagTumbuhan & ?DigunakanPada & ?Penyakit \\
44 & ?CaraPengolahan & ?CaraPengolahanPada & ?Tumbuhan \\
45 & ?CaraPengolahan & ?CaraPemakaianya & ?CaraPemakaian \\
46 & ?Penyakit & ?CaraPemakaianya & ?CaraPemkaian \\
47 & ?Penyakit & ?DiobatiOleh & ?Tumbuhan \\
\hline
\end{tabular}

Tabel 3. Rule pengetahuan

\begin{tabular}{|c|c|}
\hline Pengetahuan & Rule \\
\hline 1 & IF (Rule 11 AND Rule 12 AND Rule 13) Then Pengetahuan 1 \\
\hline 2 & IF (Rule 14 AND Rule 15) Then Pengetahuan 2 \\
\hline 3 & IF (Rule 1 AND Rule 2 AND Rule 3 AND Rule 4 AND Rule 5 AND Rule 6) Then Pengetahuan 3 \\
\hline 4 & IF (Rule 6 AND Rule 7 AND Rule 8 AND Rule 9 AND Rule 10) Then Pengetahuan 4 \\
\hline 5 & $\begin{array}{l}\text { IF (Rule } 1 \text { AND Rule } 41 \text { AND Rule } 42 \text { AND Rule } 43 \text { AND Rule } 44 \text { AND Rule } 45 \text { AND Rule } 46 \\
\text { AND Rule 47) Then Pengetahuan } 5\end{array}$ \\
\hline 6 & IF (Rule 1 AND Rule 35 AND Rule 36) Then Pengetahuan 6 \\
\hline 7 & IF (Rule 36 AND Rule 38 ) Then Pengetahuan 7 \\
\hline 8 & $\begin{array}{l}\text { IF (Rule } 1 \text { AND Rule } 35 \text { AND Rule } 36 \text { AND Rule } 37 \text { AND Rule } 39 \text { AND Rule } 40 \text { ) Then } \\
\text { Pengetahuan } 8\end{array}$ \\
\hline 9 & IF (Rule 33 AND Rule 34) Then Pengetahuan 9 \\
\hline 10 & $\begin{array}{l}\text { IF (Rule } 16 \text { AND Rule } 17 \text { AND Rule } 18 \text { AND Rule } 19 \text { AND Rule } 20 \text { AND Rule } 21 \text { AND Rule } 22 \\
\text { AND Rule } 23 \text { AND Rule } 24 \text { AND Rule } 25 \text { AND Rule } 26 \text { ) Then Pengetahuan } 10\end{array}$ \\
\hline 11 & IF (Rule 28 AND Rule 29) Then Pengetahuan 11 \\
\hline 12 & IF (Rule 27 AND Rule 30) Then Pengetahuan 12 \\
\hline 13 & IF (Rule 31 AND Rule 32) Then Pengetahuan 13 \\
\hline
\end{tabular}

\section{Mengintegrasikan Ontologi}

Model konseptual yang telah dibuat selanjutnya diimplementasikan pada toolsProtégé. Pada toolsProtégé dilakukan pendefinisian kelas dan hirarki, membuat object properties relasi antar kelas seperti "KhasiatPada", "SenyawaDari", "HabitusDari", dan lainlain, serta membuat datatype properties dengan batasannya seperti tipe data string untuk kelas tersebut, dan yang terakhir membuat individual untuk melakukan instance, untuk membuat instance diperlukan data-data yang sudah didapat sebelumnya.
Visualisasi ontologi konseptual yang sudah diimplementasikan pada Protégé dapat dilihat pada Gambar 4. Gambar 4 menjelaskan seluruh relasi antar kelas yang saling terkait dengan object properties menggunakan triple model serta memperlihatkan kelas yang mempunyai sub kelas.

\section{Encoding}

Model ontologi yang sudah diimplementasikan pada toolsProtégé direpresentasikan ke dalam format yang dapat dibaca oleh sistem, yaitu dengan format 
RDF/OWL. Aturan yang telah dibuat untuk membentuk pengetahuan direpresentasikan dalam bentuk SPARQL. Struktur klausa pada SPARQL seperti struktur triple model, untuk memastikan SPARQL yang dimodelkan.

Klausa WHERE baris 12 (?uritumbuhan rdf:type brc:Tumbuhan), dari pernyataan baris tersebut yang menyatakan variabel adalah ?uritumbuhan yang merupakan anggota dari kelas Tumbuhan. Pada baris 13 (?uritumbuhan brc:KodeTumbuhan ?kodetumbuhan) pernyataan baris tersebut adalah bahwa variabel ?uritumbuhan sebagai subyek yang mengembalikan nilai URI tumbuhan dan kode tumbuhan, brc:KodeTumbuhan berperan sebagai predikat sedangkan ?kodetumbuhan berperan sebagai variabel objek yang mengembalikan nilai kode tumbuhan. Berikut output dari query dapat dilihat pada Gambar 6.

SPARQL yang telah didesain dan diuji dapat diaplikasikan pada sistem yang dibangun.

\section{Pengembangan Sistem Aplikasi}

Bahasa RDF/OWL hanya dimengeri oleh komputer dan tidak dapat langsung digunakan langsung untuk ditampilkan pada antar muka yang dilihat oleh orang

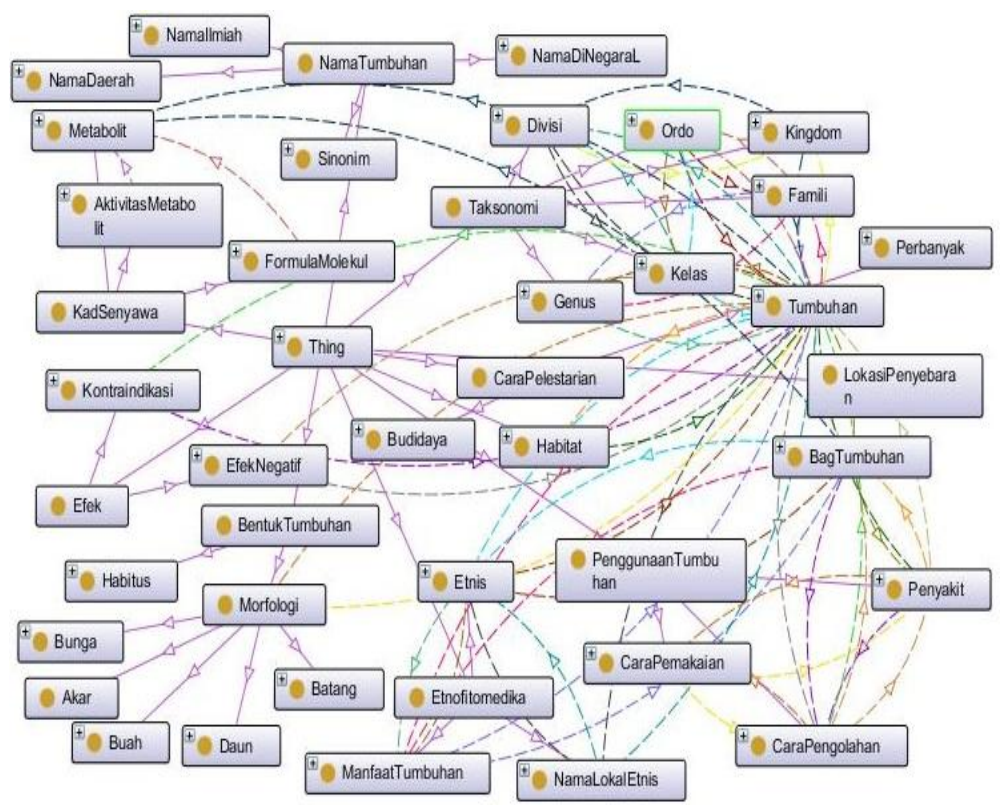

Gambar 4. Visualisasi relasi antar kelas

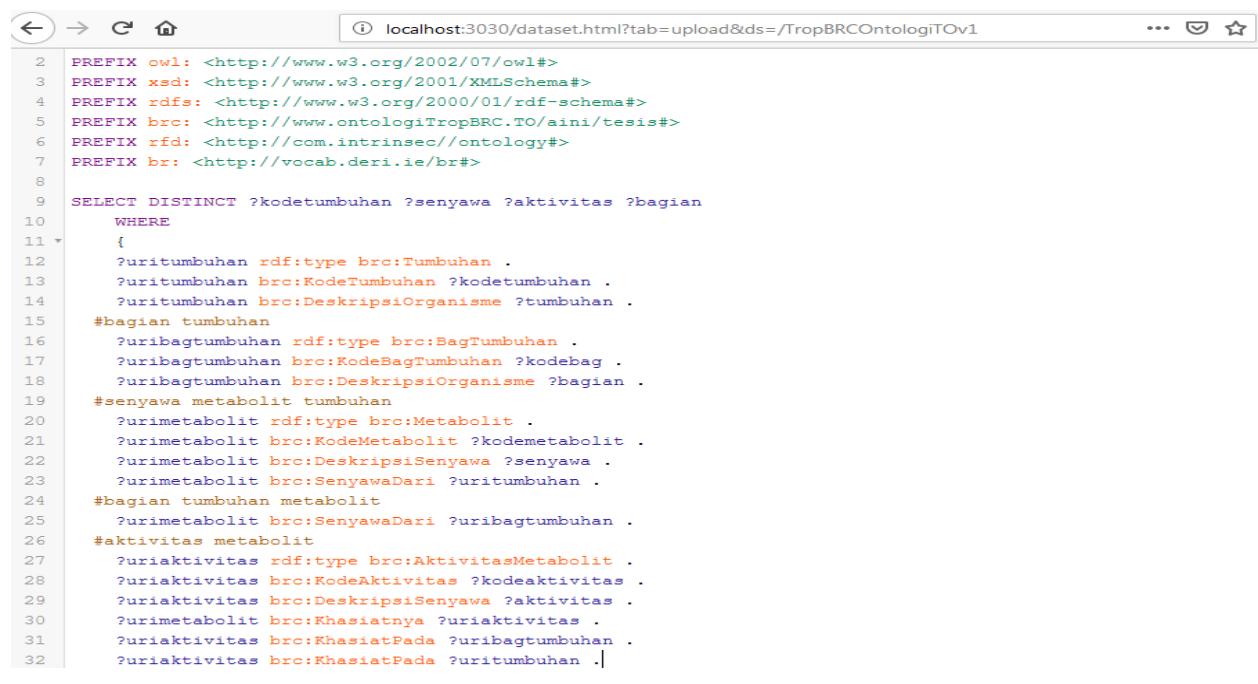

Gambar 5. Pengujian SPARQL untuk melihat aktivitas metabolit 
awam karena terlalu tekni. User tidak perlu mengetahui bagaimana cara menyimpan informasi atau memahami query untuk meminta pengetahuan dari tumbuhan obat. Oleh karena itu, sistem membutuhkan perantara yang mudah dipahami oleh pengguna akhir. Berdasarkan kebutuhan, maka dirancang arsitektur sistem yang dapat dilihat pada Gambar 7.

Sistem memiliki tiga buah lapis, yaitu lapisan ontologi, lapisan server, dan lapisan antarmuka. Lapisan ontologi merupakan basis pengetahuan yang dimiliki sistem. Basis pengetahuan terdiri dari data yang telah distruktur menggunakan ontologi. Lapisan ontologi berinteraksi langsung dengan lapisan server.
Pengembangan sistem aplikasi diimplementasikan pada perangkat mobile dan dilakukan pengujian fungsionalitas menggunakan metode blackbox testing, berikut tampilan sistem dapat dilihat pada Gambar 8 . Sistem aplikasi ini memiliki empat menu yaitu menu tumbuhan obat, penyakit, senyawa, dan help. Pada menu tumbuhan obat dapat dilihat detail pengetahuan dari tumbuhan obat meliputi taksonomi, cara melestarikan, habitat, morfologi dan lain-lain. Pada menu penyakit terdapat pengolahan tumbuhan berdasarkan penyakit tertentu. Pada menu senyawa terdapat detail pengetahuan senyawa metabolit meliputi cas id, formula molekul, berat molekul serta aktivitas metabolit sebagai khasiat obat. Pada menu help berisi penjelasan dari menu tumbuhan obat, senyawa, dan penyakit.
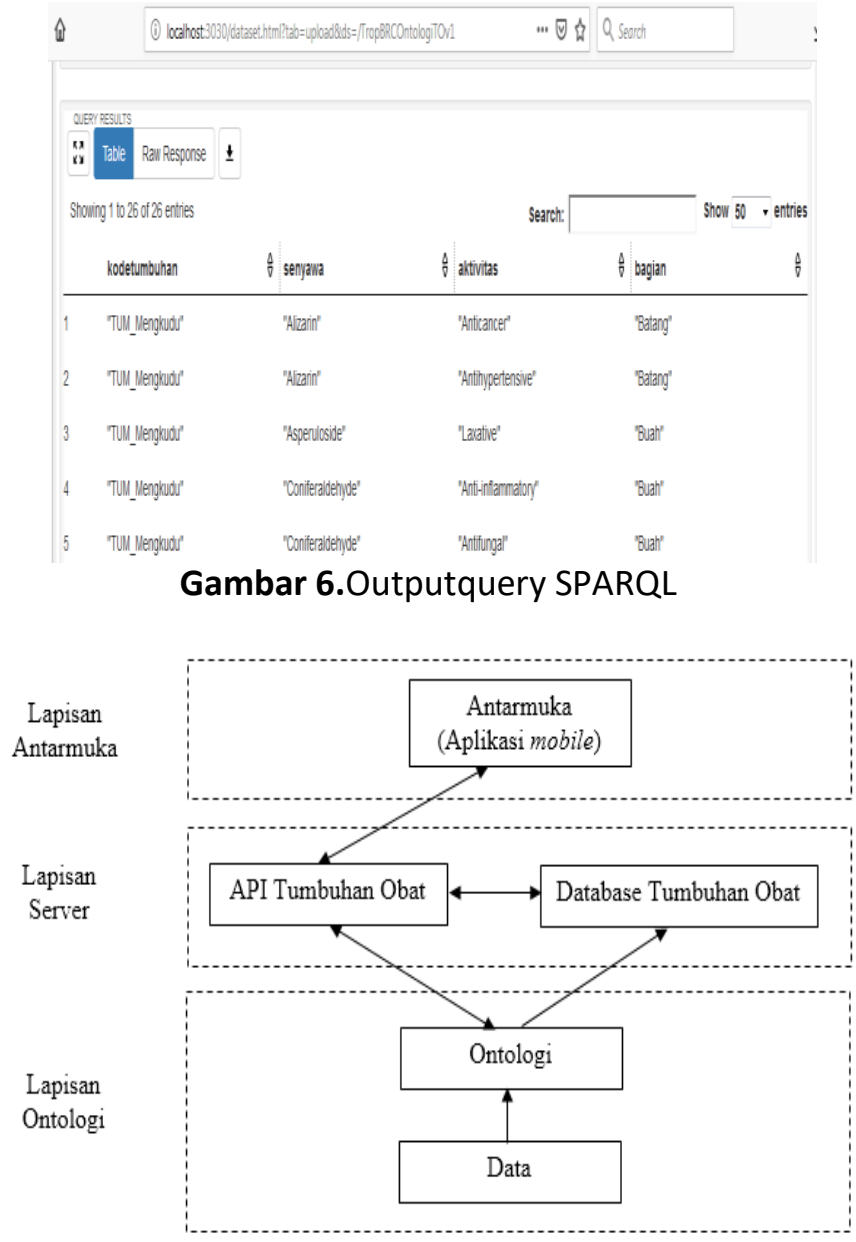

Gambar 7.Arsitektur system

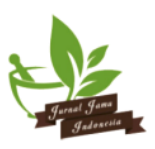




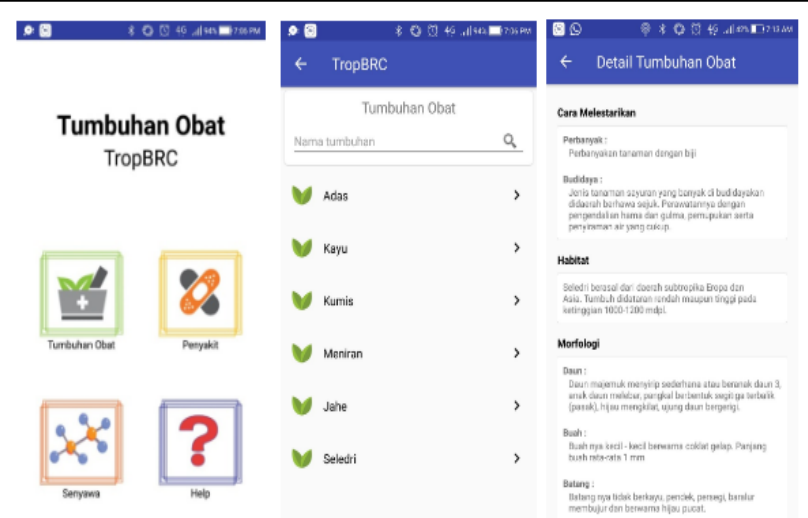

Gambar 8.Tampilan aplikasi mobile

\section{KESIMPULAN}

Model ontologi dapat diterapkan untuk pengembangan sistem berbasis pengetahuan tumbuhan obat. Pengetahuan yang digunakan mengenai tumbuhan obat dan senyawa metabolit sekunder beserta pengetahuan dasar dari tumbuhan seperti cara melestarikan, habitat, morfologi dan lainlain. Ontologi direpresentasikan dalam bentuk RDF/OWL, model ontologi tumbuhan obat menghasilkan pengetahuan dengan melakukan query menggunakan SPARQL. Hasil query tersebut dapat digunakan untuk diimplementasikan ke dalam sistem aplikasi mobile.

\section{UCAPAN TERIMA KASIH}

Ucapan terima kasih diberikan untuk Pusat Studi Biofarmaka Tropika LPPM sebagai tempat untuk penelitian.

\section{DAFTAR PUSTAKA}

Babu MSP, Govathoti S. 2016. A semantic model for building integrated ontology database. 2016 7th IEEE International Conference on Software Engineering and Service Science (ICSESS).doi: 10.1109/ICSESS.2016.7883140.

Chen C, Fu R. 2010. A new frame of tacit knowledge transfer based on ontology. Knowledge Creation Diffusion Utilization, FSKD. 1756-1760.

[ljah] Indonesia Jamu- Herbs. 2017. Mencari prediksi tumbuhan dan senyawa [Internet]. Institut Pertanian Bogor. Tersedia pada: http://ijah.apps.cs.ipb.ac.id/\#/home.
Khan SU, Khan M, Nauman M. 2017. Semi-automatic knowledge transformation of semantic network ontologies into frames structures. 2016 6th International Conference on Innovative Computing Technology, INTECH 2016. 712-717.

Nonaka I. 1994. A dynamic theory of organization knowledge creation. Organization Science. 5(1)(February): 14-37.

Ribino P, Oliveri A, Re GL, Gaglio S. 2009. A knowledge management system based on ontologies. International Conference on New Trends in Information and Service Science. 1025-1033.

Sanjaya S. 2014. Pengembangan ontologi tumbuhan obat Indonesia menggunakan Etnobotani [tesis]. Bogor (ID): Institut Pertanian Bogor.

Silalahi M, Cahyani DE, Sensuse DI, Budi I. 2015. Developing Indonesian medicinal plant ontology using socio-technical approach. I4CT 2015 - 2015 2nd International Conference on Computer, Communications, and Control Technology, Art Proceeding, (14). 39-43.

Sir M, Bradac Z, Fiedler P. 2015. Ontology versus database. Science Direct, IFAC-PapersOnLine. 48(4):220-225. doi.org/10.1016/j.ifacol.2015.07.036

Stevens R, Goble C, Bechhofer S. 2000. Ontology-based knowledge representation for bioinformatics. Briefings in Bioinformatics. 1(4):398-414.

Zhu Q, Tao C. 2014. Pharmacological class data representation in the Web Ontology Language (OWL). Proceedings - 2014 IEEE International Conference on Big Data, IEEE Big Data 2014. 77-84. doi:10.1109/BigData.2014.7004397. 